\title{
CHANGES IN LIVER AND BRAIN CYTOCHROME P450 AFTER MULTIPLE COCAINE ADMINISTRATION, ALONE AND IN COMBINATION WITH NIFEDIPINE**
}

\author{
Vessela VITCHEVA and Mitka MITCHEVA \\ Laboratory of "Drug metabolism and drug toxicity", Department of "Pharmacology and \\ Toxicology", Faculty of Pharmacy, Medical University, Sofia, Bulgaria \\ Received in December 2006 \\ Accepted in March 2007
}

\begin{abstract}
The objective of this study was to evaluate possible changes caused by multiple cocaine administration, alone and in combination with 1,4-dihydropiridine calcium channel blocker nifedipine, on cytochrome P450 levels both in the brain and liver. The experiment was done on male Wistar rats divided in four groups: control, treated with nifedipine (5 mg kg-1 i.p. for five days), treated with cocaine (15 mg kg-1 i.p. for five days), and treated with nifedipine and 30 minutes later with cocaine (also for five days). Total cytochrome P450 was measured spectrometrically in liver and brain microsomes. Multiple administration of cocaine alone and in combination with nifedipine did not change the brain P450 significantly. In the liver, nifedipine significantly increased P450 by $28 \%$ vs. control. In contrast, cocaine significantly decreased P450 by $17 \%$ vs. control. In animals treated with nifedipine and cocaine, cytochrome P450 increased $11 \%(\mathrm{p}<0.01)$ vs. control, decreased $12.5 \%$ ( $p<0.001)$ vs. nifedipine group and increased $34 \%$ ( $<<0.0001)$ vs. cocaine group. These results suggest that the cocaine and nifedipine interact at the metabolic level.
\end{abstract}

KEY WORDS: calcium channel blocker, metabolism, microsomes, in vivo interactions

Cocaine is an alkaloid psychostimulant with high addictive potential. It has a high affinity for the transporters of dopamine, serotonine and noradrenaline, and blocks their reuptake (1).

Cocaine is extensively metabolized in humans and animals by hepatic and plasma esterases to pharmacologically inactive benzoylecgonine, ecgonine methyl ester (2), and an active metabolite, norcocaine, the product of $\mathrm{N}$-demethylation. Isoenzymes involved in cocaine $\mathrm{N}$-demethylation show species differences. In humans and mice cocaine is $\mathrm{N}$-demethylated by CYP $3 \mathrm{~A}$, and in rats by both CYP $3 \mathrm{~A}$ and CYP $2 \mathrm{~B}$ (3). The involvement of CYP 3A4 in cocaine metabolism implies possible metabolic interactions with other substrates of this isoenzyme, including $\mathrm{Ca}^{2+}$ channel blockers nifedipine, nimodipine, and amlodipine (4).
Literature data suggest that L-type calcium channels play a principal role in the regulation of adaptive changes in the central nervous system (5). Blockers of these channels are interesting for their potential application as anti-addiction agents, as they appear to play a principal role in the regulation of adaptive changes in the central nervous system by maintaining different types of drug dependence and withdrawal, including those induced by psyhostimulants (6). In our earlier studies (7) we have demonstrated that nifedipine, co-administered with morphine, attenuates the symptoms of opiate withdrawal that correlated with the changes in neuronal nitric oxide synthase (nNOS). At the same time we observed interactions between morphine and nifedipine in the liver.

\footnotetext{
* Partly presented at the EUROTOX 2006/6 CTDC Congress, Cavtat, Croatia, 20-24 September 2006.
} 
Since cocaine and the 1,4-dihydropyridine calcium blocker nifedipine are substrates of one and the same cytochrome P450 isoenzyme CYP 3A4, the aim of this study was to investigate possible P450-mediated interactions between the two compounds both at the hepatic and brain level.

\section{MATERIALS AND METHODS}

\section{Animals}

Male Wistar rats (weighing $200 \mathrm{~g} \pm 10 \mathrm{~g}$ ) were housed under standard laboratory conditions at $20^{\circ} \mathrm{C}$, with $12 \mathrm{~h}$ alternating light/dark cycles and free access to food and water. The animals were purchased from the National Breeding Centre, Slivnitza, Bulgaria. The principles stated in the European Convention for the Protection of Vertebrate Animals used for Experimental and other Scientific Purposes (ETS 123) (1991) (8) were strictly followed throughout the experiment.

\section{Design of the experiment}

The animals were divided into four groups $(\mathrm{n}=6$ each). The first group was receiving nifedipine at doses of $5 \mathrm{mg} \mathrm{kg}^{-1}$ i.p. once a day for five days (9). The second group was receiving $15 \mathrm{mg} \mathrm{kg}^{-1}$ i.p. of cocaine once a day for five days (10). The third group was receiving nifedipine (5 mg kg${ }^{-1}$ i.p) and $30 \mathrm{~min}$ after that cocaine $\left(15 \mathrm{mg} \mathrm{kg}^{-1}\right.$ i.p.). This combination was also administered once a day for 5 days.

The fourth group included control, untreated animals, which were involved in the experiment from the very beginning and housed under the same standard laboratory conditions as the treated animals.

Biochemical parameters were evaluated 24 hours after the last administered dose.

\section{Drugs used}

The drugs used in this study were cocaine hydrochloride (Sigma, Germany) and nifedipine hydrochloride (Sigma, Germany).

\section{Preparation of brain and liver microsomes for assessment of cytochrome P450}

Freshly removed whole brains were rinsed with $0.15 \mathrm{~mol} \mathrm{~L}^{-1} \mathrm{KCl}$ three times and homogenised with nine volumes of Tris buffer, $\mathrm{pH}=7.4$, according to the method of Bhagwat et al., (11). The livers were perfused with $0.15 \mathrm{~mol} \mathrm{~L}^{-1} \mathrm{KCl}$, excised and minced. The latter was homogenised with three volumes of $1.17 \% \mathrm{KCl}$ solution in a glass homogeniser, as described by Guengerich (12). The brain and liver homogenates were then centrifuged at $10,000 \mathrm{x}$ for $20 \mathrm{~min}$. The supernatant fractions were centrifuged at $105,000 \mathrm{x} \mathrm{g}$ for $60 \mathrm{~min}$. The resulting microsomal pellets were stored at $-20^{\circ} \mathrm{C}$ until the assay. At the day of assay the microsomal pellets were resuspended and diluted in phosphate buffer $+1 \mathrm{mmol} \mathrm{L}^{-1}$ EDTA ( $\mathrm{pH}=7.4)$.

Cytochrome P450 was quantified spe= ctrophotometrically as a complex with $\mathrm{CO}$, at $450 \mathrm{~nm}$ (13) and expressed in $\mathrm{nmol} / \mathrm{mg}^{-1}$ protein (14).

\section{Statistical analysis}

The results are presented as mean values $( \pm S D)$ of six animals per group. For the analysis we used Student's $t$-test. Probability values less than 0.05 were considered significant.

\section{RESULTS}

Table 1 shows the effects of multiple administration of cocaine and nifedipine on the quantity of hepatic cytochrome P450. Both compounds, administered alone, influenced the enzyme quantity in a statistically significant fashion, as follows: nifedipine increased it by $28 \%(p<0.001)$, while cocaine decreased it by $17 \%(p<0.001)$ us. control. In the combination group the P450 quantity increased $11 \%(\mathrm{p}<0.01)$ versus control, decreased $12.5 \%$ ( $<<0.001)$ us. nifedipine, and increased $34 \%(\mathrm{p}<0.0001)$ us. cocaine group.

Table 2 shows changes in the quantity of cytochrome P450 in rat brain after multiple administration of cocaine and nifedipine. Both compounds, applied alone or in combination, did not significantly change the quantity of brain cytochrome P450.

\section{DISCUSSION}

L-type calcium channel blockers of the dihydropyridine class, such as nifedipine, nimodipine, amlodipine, have been reported to affect different types of drug dependence and withdrawal, including those to opioides (15), alcohol (16), psychostimulants (10). At the same time they are known to be the 
Table 1 Quantity of cytochrome P450 in rat liver after multiple administration of cocaine and nifedipine

\begin{tabular}{lcccc}
\hline Group & Cyt P450 $/ \mathrm{nmol} \mathrm{mg}^{-1}$ & $\begin{array}{c}\text { Effect } v \text { s. } \\
\text { control } / \%\end{array}$ & $\begin{array}{c}\text { Effect } v s . \\
\text { nifedipine } / \%\end{array}$ & $\begin{array}{c}\text { Effect } v s \text { s. } \\
\text { cocaine } / \%\end{array}$ \\
\hline Control & $0.346 \pm 0.022$ & 100 & - & - \\
Nifedipine & $0.439 \pm 0.007^{* *}$ & 128 & 100 & - \\
Cocaine & $0.286 \pm 0.010^{* *++}$ & 83 & 65 & 100 \\
Nifedipine+ Cocaine & $0.384 \pm 0.006^{*+*}$ & 111 & 87.5 & 134 \\
\hline
\end{tabular}

${ }^{*} p<0.01, * * p<0.001$ us. control

${ }^{+} p<0.01 ;{ }^{++} p<0.001$ us. nifedipine group

${ }^{\#} p<0.0001$ us. cocaine group

Table 2 Quantity of cytochrome P450 in rat brain after multiple administration of cocaine and nifedipine

\begin{tabular}{lcc}
\hline Group & Cyt P450 / nmol mg & \\
\hline Control & $0.098 \pm 0.002$ & Effect us. control / \% \\
Nifedipine & $0.101 \pm 0.002$ & 100 \\
Cocaine & $0.096 \pm 0.002$ & 103 \\
Nifedipine + Cocaine & $0.099 \pm 0.001$ & 98 \\
\hline
\end{tabular}

substrates of one of the most abundant cytochrome P450 isoenzyme CYP3A that interacts with other substrates of this isoform, including cocaine.

Cocaine is a well-known and widespread psychostimulant; it causes behavioural changes, tolerance, and development of dependence. There is a close relationship between drug metabolism and dependence development. Haward et al. (17) studied the role of pharmacogenetically variable cytochrome P450 in drug abuse and dependence, and concluded that there are significant implications related to drug toxicity, drug-drug interactions, and abuse.

The objective of this study was to investigate the effects of multiple administration of cocaine, alone and in combination with nifedipine, on the quantity of cytochrome P 450 in rat liver and brain. Our results showed that in the liver, cocaine and nifedipine had the opposite effect; compared to the control, cocaine significantly reduced cytochrome $P$ 450 , while nifedipine led to its statistically significant increase. Nifedipine is known to induce cytochrome $P$ $450(18,19)$. The available data on cocaine effects on drug-metabolising enzymes are controversial. Shuster at al. (20) focused on cocaine's hepatotoxicity due to its metabolism. They presented evidence that cocaine administered chronically damaged the liver, and discussed the possibility that cocaine itself induced mixed-function oxidase in the smooth endoplasmic reticulum. Later studies have demonstrated that subacute cocaine treatment accounts for increased $\mathrm{N}$ hydroxilation of norcocaine in the mouse liver (21).
On the other hand, there are studies showing cocaine as an inhibitor of some polymorphic CYPs, such as CYP2D6 (17). The results of our study correlate with the results obtained by Pasanen et al. (22). They show that repeated cocaine administration for up to five days decreases CYP1A1/2, 2A4/5, 2CX and 2E1-related enzyme activities.

In the combination group changes in P450 quantity showed that neither nifedipine nor cocaine could exert their effects. These results could be explained by the metabolism of the compounds and their possible interactions on this level. Nifedipine has been reported to be the sustrate of cytochrome P450 (CYP) 3A subfamily (4), and some of the administered cocaine is metabolised to the $\mathrm{N}$-demethylated form, norcocaine, possibly by the same subfamily (2). Thus, these two compounds could be substrate competitors for CYP 3A, and this is one possible explanation of our results.

On the brain level, our results revealed that cocaine and nifedipine, alone and in combination, did not significantly change the quantity of cytochrome P450. It is known that the quantity of brain cytochrome is only about $3 \%$ of that of the liver (11). Our data correlate with the results of Nabeshima T. et al. (23) who assessed the effects of morphine and phenobarbital on brain cytochrome P450. In view of its low brain levels, it is quite likely that brain cytochrome P450 does not play a significant role in brain metabolism.

In conclusion, the changes in the quantity of liver cytochrome P450 observed in our study after 
multiple co-administration of nifedipine and cocaine suggest that these compounds mutually influenced each other's metabolism, which led to changes in their pharmacokinetics. The influence on cocaine pharmacokinetics could affect the development of cocaine dependence and withdrawal syndrome, which is a matter of future investigations.

\section{REFERENCES}

1. Filip M, Frankowska M, Zaniewska M, Golda A, Przegalinski E. The serotonergic system and its role in cocaine addiction. Pharmacol Rep 2005;57:685700.

2. Sun L, Lau CE. Simultaneous pharmacokinetic modeling of cocaine and its metabolites, norcocaine and benzoylecgonine, after intravenous and oral administration in rats. Drug Metab Dispos 2001;29:1183-9.

3. Arinc E, Bozcaarmutlu A. Catalyzation of cocaine N-demethylation by cytochromes P4502B, P4503A, and P4502D in fish liver. J Biochem Mol Toxicol 2003;17:169-76.

4. Liu XQ, Ren YL, Qian ZY, Wang GJ. Enzyme kinetics and inhibition of nimodipine metabolism in human liver microsomes. Acta Pharmacol Sin 2000;21:690-4.

5. Vetulani J. Calcium and voltage-dependent calcium channels. Kismos 1997;46:491-505.

6. etulani J. Drug addiction. Part III. Pharmacotherapy of addiction. Pol J Pharmacol 2001;53:415-35.

7. Vitcheva V, Mitcheva M. Effects of Nifedipine on behavioral and biochemical parameters in rats after multiple morphine administration. Methods Find Exp Clin Pharmacol 2004;26:631-4.

8. Council of Europe. European Convention for the Protection of Vertebrate Animals used for Experimental and other Scientific Purposes. CETS No. 123, 1991. [displayed 30 May 2007] Available at http:// conventions.coe.int/Treaty/Commun/QueVoulezVous. asp?NT $=123 \varepsilon C M=1 \varepsilon C L=E N G$.

9. Antkiewicz-Michaluk L, Romanska I, Vetulani J. $\mathrm{Ca}^{2+}$ channel blockade prevents lysergic acid diethylamide-induced changes in dopamine and serotonin metabolism. Eur J Pharmacol 1997;332:914.

10. Itzhak Y, Ali SF, Martin JL, Black MD, Huang PL. Resistance of neuronal nitric oxide synthase-deficient mice to cocaine-induced locomotor sensitization. Psychopharmacol 1998;140:378-86.

11. Bhagwat SV, Boyd MR, Ravindranath V. Rat brain cytochrome P 450. Reassessment of monooxygenase activities and cytochrome P450 levels. Drug Metab Disps 1995;23:651-4.

12. Guengerich FP. Microsomal enzymes involved in toxicology. Analysis and separation. In: Heis AW, editor. Principals and Methods of Toxicology. New York (NY): Raven Press; 1987. p. 609-634.

13. Omura T, Sato R. The carbon-monoxide-binding pigment of liver microsomes. J Biol Chem 1964;239:2370-85.

14. Lowry OH. Protein measurement with the Folin phenol reagent. J Biol Chem 1951;193:265-75.

15. Antkiewicz-Michaluk L, Michaluk J, Romanska I, Vetulani J. Reduction of morphine dependence and potenciation of analgesia by co-administration of nifedipin. Biopharmacol 1993;111:457-67.

16. Watson WP, Little JJ. Effects of dihydropiridines on the components of the ethanol withdrawal syndrome: possible evidence for involvement of potassium, as well as calcium? Alcohol Clin Exp Res 1997;21:409-16.

17. Haward LA, Sellers EM, Tyndale RF. The role of pharmacogenetically - variable cytochrome P450 in drug abuse and dependence. Pharmacogenomics 2002;3:185-99.

18. Koleva MR, Stoychev TS. Effect of nifedipine, verapamil and diltiazem on the enzyme-inducing activity of phenobarbital and beta-naphthoflavone. Gen Pharmacol 1995;26:225-8.

19. Kastelova A, Koleva M, Staneva-Stoytcheva D. Changes in rat liver monooxygenase activities after administration of atenolol, nifedipine and diltiazem alone and in combination. Methods Find Exp Clin Pharmacol. 2000;22:627-31.

20. Shuster L, Garhart C, Powers J, Grunfeld Y, Kanel G. Hepatotoxicity of cocaine. NIDA Res Monogr 1988;88:250-75.

21. Powers JF, Shuster L. Subacute cocaine treatment changes expression of mouse liver cytochrome P450 isoforms. Pharmacology 1999;58:87-100.

22. Pasanen M, Pellinen P, Stenback F, Juvonen RO, Raunio $\mathrm{H}$, Pelkonen $\mathrm{O}$. The role of CYP enzymes in cocaineinduced liver damage. Arch Toxicol 1995;69:287-90.

23. Nabeshima T, Fontenit J, Ho IK. Effect of chronic administration of phenobarbital or morphine on the brain micrisomal cytochrome P450 system. Biochem Pharmacol 1981;30:1142-5. 


\section{Sažetak}

\section{PROMJENE CITOKROMA P450 JETRE I MOZGA NAKON VIŠEKRATNE PRIMJENE KOKAINA, SAMOG} ILI U KOMBINACIJI S NIFEDIPINOM

Cilj je ovog istraživanja bio ocijeniti moguće promjene uzrokovane višestrukom primjenom kokaina kao jedinog agensa odnosno u kombinaciji s nifedipinom, 1,4-dihidropiridinskim blokatorom kalcijevih kanala, na razine citokroma P450 u mozgu i jetri štakora. Životinje (mužjaci Wistar štakora) podijeljene su u četiri skupine: kontrolnu skupinu, skupinu koja je primala nifedipin ( $5 \mathrm{mg} \mathrm{kg}^{-1}$ ip. pet dana), skupinu koja je primala kokain (15 mg kg-1 ip. pet dana) i skupinu koja je primala nifedipin te pola sata kasnije kokain (također pet dana). Ukupna količina citokroma P450 mjerena je spektrofotometrijski u mikrosomima jetre i mozga. Višestruka primjena samo kokaina odnosno u kombinaciji s nifedipinom nije značajno promijenila razine citokroma P450 u mozgu. U jetri je međutim nifedipin u odnosu na kontrolnu skupinu uzrokovao povišenje razina P450, za statistički značajnih $28 \%$. Kokain je uzrokovao statistički značajan pad razine P450 za 17 \% u odnosu na kontrolnu skupinu. U životinja koje su primale kombinaciju nifedipina i kokaina razina citokroma P450 narasla je za $11 \%(p<0.01)$ u odnosu na kontrolu, bila je $12.5 \%(p<0.001)$ niža u odnosu na skupinu koja je primala nifedipin te viša za 34 \% $(\mathrm{p}<0.0001)$ u odnosu na skupinu koja je primala samo kokain. Rezultati ovog istraživanja upućuju na interakcije ovih spojeva koje se odvijaju na razini metabolizma.

KLJUČNE RIJEČI: blokator kalcijevih kanala, interakcije in vivo, metabolizam, mikrosomi

\section{CORRESPONDING AUTHOR:}

Vessela Vitcheva

Faculty of Pharmacy

Department of Pharmacology and Toxicology

Dunav str. 2; Sofia 1000; Bulgaria

E-mail: vesselavitcheva@yahoo.com 